CLINICAL STUDY

\title{
Peripheral insulin-like factor 3 concentrations are reduced in men with type 2 diabetes mellitus: effect of glycemic control and visceral adiposity on Leydig cell function
}

\author{
F Ermetici $^{1,2}$, F Donadio ${ }^{2}$ L Iorio $^{1}$, A E Malavazos $^{1}$, A Dolci $^{3}$, E Peverelli $^{2}$, A M Barbieri $^{2}$, L Morricone $^{1}$, I Chiodini $^{2}$,

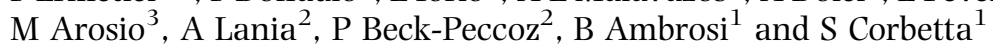 \\ ${ }^{1}$ Endocrinology and Diabetology Unit, Department of Medical-Surgical Sciences, Università degli Studi di Milano, IRCCS Policlinico San Donato, \\ Via Morandi 30, 20097 San Donato Milanese, Milano, Italy, ${ }^{2}$ Endocrine Unit, Department of Medical Sciences, IRCCS Fondazione Ospedale Maggiore \\ Policlinico, Mangiagalli e Regina Elena, 20122 Milan, Italy and ${ }^{3}$ Endocrinology Unit, Department of Medical Sciences, S. Giuseppe Hospital of Milan, \\ Università degli Studi di Milano, 20123 Milan, Italy
}

(Correspondence should be addressed to S Corbetta; Email: sabrina.corbetta@unimi.it)

\begin{abstract}
Background and aim: Hypogonadism frequently occurs in men with type 2 diabetes mellitus (T2DM), while the role of glycemic control and visceral obesity is still unclear. This study aimed to assess the Leydig cell function, including the new sensitive marker insulin-like factor 3 (INSL3), in T2DM patients without overt hypogonadism and the influence of either glycemic control or visceral adiposity. Subjects and methods: Thirty T2DM patients (age 57.1 \pm 6.2 years, body mass index (BMI) 28.0 \pm 4.3 ) without overt hypogonadism and 30 age- and BMI-matched controls were studied. Anthropometric, glycometabolic parameters and testosterone, SHBG, LH, INSL3 levels, bioavailable and free testosterone (BT and cFT) were evaluated. The human chorionic gonadotrophin (hCG) test was also performed.

Results: Patients had lower total testosterone $(452.6 \pm 130.0$ vs $512.6 \pm 117.3 \mathrm{ng} / \mathrm{dl}, P=0.06)$, BT $(189.7 \pm 36.4$ vs $237.1 \pm 94.1 \mathrm{ng} / \mathrm{dl}, P=0.002)$, cFT $(8.1 \pm 1.6$ vs $10.1 \pm 4.0 \mathrm{ng} / \mathrm{dl}, P=0.002)$, and higher LH levels $(3.5 \pm 1.6$ vs $2.6 \pm 1.2 \mathrm{mU} / \mathrm{ml}, P=0.01)$ versus controls. Serum INSL3 concentrations were also lower in patients $(1.1 \pm 0.3 \mathrm{vs} 1.5 \pm 0.7 \mathrm{ng} / \mathrm{ml}, P=0.01)$. These hormonal parameters, including INSL3, did not differ between T2DM patients with poor or good glycemic control (HbAlc $>9$ or $<7 \%$ respectively). In patients, waist circumferences $(97.9 \pm 12.4 \mathrm{~cm})$ negatively correlated with INSL3 $(P=0.03)$ and basal, as well as hCG-stimulated testosterone levels $(P=0.04$ and 0.004 respectively). Basal or stimulated hormonal levels and INSL3 concentrations were not different between patients with $(40 \%)$ or without erectile dysfunction.

Conclusions: An early impairment of the overall Leydig cell function is present in men with T2DM, mainly related to visceral adiposity rather than to glycemic control.
\end{abstract}

European Journal of Endocrinology 161 853-859

\section{Introduction}

A frequent occurrence of overt hypogonadism has been reported in men with type 2 diabetes mellitus (T2DM). However, different criteria have been used for defining hypogonadism in diabetic men, including biochemical evidence of hypogonadism, as suggested by low total or free testosterone levels, or the association of both symptoms and biochemical evidence of testosterone deficiency (1-7). In addition, the mechanisms underlying the low testosterone levels in male diabetic subjects and the effect of T2DM comorbidities, such as visceral obesity, remain still unclear. Several studies investigating the hypothalamic-pituitary-gonadal (HPG) axis in T2DM gave conflicting results. Indeed, either hypo- or hypergonadotropic hypogonadism has been reported (2, 8-10). A recent study demonstrated an association between insulin resistance and a primitive alteration in Leydig cell function in men with various degrees of insulin resistance (11). Nonetheless, the presence of subtle alterations of Leydig cells function in diabetic patients with normal testosterone values has not been fully elucidated.

Contrasting results have also been reported for the relationship between glycemic control and HPG function (1-3, 5, 7, 12-14). Visceral obesity, an important cause of insulin resistance and T2DM, has also been involved in the regulation of Leydig cell function. Previous studies showed that obesity and visceral adiposity, as assessed by both body mass index (BMI) and waist circumference, are negatively associated with the traditional marker of impaired Leydig 
cell steroidogenesis, serum testosterone, in T2DM (2-4, $6,7)$. Studies investigating the role of both degrees of glycemic control and visceral obesity on the HPG function in T2DM patients are not currently available.

Recently, insulin-like factor 3 (INSL3), a member of the insulin-relaxin superfamily of peptide hormones, has been used as a specific marker of Leydig cell differentiation and function, since it appears more sensitive than testosterone itself in evaluating function (15). Previous reports investigated INSL3 concentrations in adult normal subjects and in men with different testicular disorders, showing a lower amount in subjects with testicular damage $(15,16)$ and a decrease in its concentration with aging in normal men (17). INSL3 measurement, as a parameter of the HPG axis impairment, has not been reported in T2DM up to now.

The aim of the present study was to investigate the Leydig cell function and its relationship with either glycemic control or visceral adiposity in a wellcharacterized series of patients affected with T2DM without overt hypogonadism and with different degrees of glycemic control.

\section{Subjects and methods}

\section{Study population}

Thirty men with T2DM (age $57.1 \pm 6.2$ years, BMI $28.0 \pm 4.3 \mathrm{~kg} / \mathrm{m}^{2}$ ) referred to our units for the management of diabetes were enrolled. Patients affected with overt hypogonadism, defined on the basis of low calculated free testosterone (cFT) levels lower than $5 \mathrm{ng} / \mathrm{dl}$ (18), were excluded from the study. Other exclusion criteria, to avoid the effect of many confounding factors affecting the HPG axis function, were age $>65$ years, severe obesity (BMI $\geq 40 \mathrm{~kg} / \mathrm{m}^{2}$ ), past or present history of alcohol abuse ( $>40 \mathrm{~g} / \mathrm{die})$, a known history of hypogonadism, hypopituitarism, use of drugs interfering with androgen synthesis or action, past history of stroke, past or present history of malignancy, cirrhosis, chronic liver disease, chronic respiratory disease or sleep apnea syndrome, known HIV infection, hemochromatosis and varicocele. Patients with known acute infections, including low urinary tract infections, were also excluded from the study, and both end-stage renal disease and C-reactive protein values were measured in all patients to exclude current asymptomatic inflammatory states. The presence of thyroid dysfunction, hyperprolactinemia, or hypercortisolism was ruled out. Patients with severe diabetic complications were also excluded on the basis of decreased glomerular filtration rate (GFR; defined by a GFR of $<60 \mathrm{ml} / \mathrm{min}$ per $1.73 \mathrm{~m}^{2}$ ), decreased left ventricular ejection fraction (EF; diagnosed with a value of $\mathrm{EF}$ $<50 \%$ ), proliferative retinopathy (diagnosed through fundus oculi examination), diabetic neuropathy (defined as increase in vibratory perception threshold measured at lower extremity with biothesiometer), and diabetic foot ulcer. Criteria for eligibility included poor (but nonketotic) or optimal glycemic control (defined as glycated hemoglobin levels $>9$ or $<7 \%$, i.e. 15 cases respectively for each subset) for at least 2 months before the evaluation.

Seven patients were treated with diet alone, seven with insulin, and 16 with oral hypoglycemic agents. Thirteen patients were affected with blood hypertension and seven patients were dyslipidemic.

Thirty volunteer age- and BMI-matched healthy men (age $54.4 \pm 7.0$ years, BMI $26.5 \pm 2.9 \mathrm{~kg} / \mathrm{m}^{2}$ ) without hypogonadism were enrolled as controls.

Written informed consent was obtained by all patients and healthy subjects, and the study was approved by the local ethics committees.

\section{Study design and laboratory determinations}

The enrolled patients underwent the following detailed evaluation: clinical history collection and physical examination were performed. The presence of erectile dysfunction (ED) was investigated: patients with ED were further interviewed using the previously validated SIEDY structured interview (19) to assess the organic (scale 1 score), relational (scale 2 score), and psychogenic (scale 3 score) contributions to ED. Moreover, a 12-item interview, ANDROTEST (20), was performed in patients with $\mathrm{ED}$ to evaluate the presence of symptoms of hypogonadism: the test was considered pathological with a score $>8$. Anthropometric measurements included height, weight, waist, and hip circumferences. The waist-to-hip ratio (WHR) was calculated. Visceral obesity was defined as waist circumference $\geq 94 \mathrm{~cm}$ (21). Body composition was evaluated in patients by body bioelectrical impedance analysis (BIA), using BIA-101/S body fat analyser (AKERN, Florence, Italy). Blood samples were collected after an overnight fasting between 0800 and $0900 \mathrm{~h}$, for determination of glucose, total and high density lipoprotein cholesterol, triglycerides, albumin, prostate specific antigen (PSA), HbA1c (by standard laboratory methods) levels in all patients. Serum total testosterone, SHBG and LH levels were assessed by an immunofluorometric assay (PerkinElmer AutoDELFIA, Wallac Oy, Turku, Finland) in all patients and controls. To correct the total testosterone concentration for the effect of variable binding with SHBG in subjects with T2DM, free and bioavailable testosterone (cFT and BT) were calculated from testosterone, SHBG, and albumin according to the method of Vermeulen et al. (22), which has been demonstrated to correlate with free testosterone measured by equilibrium dialysis (23).

Serum testosterone levels were evaluated also after 5000 IU human chorionic gonadotrophin (hCG) i.m. at 24,72 , and $96 \mathrm{~h}$ following the injection in both patients and controls. 


\section{INSL3 EIA assay}

Serum INSL3 concentrations were measured by a commercially available EIA kit (Phoenix Pharmaceuticals, Belmont, CA, USA) in all patients and controls. All samples were measured at least in duplicates. The INSL3 EIA assay was declared highly specific for the human peptide by the manufacturer (100\% cross-reactivity with the human INSL3, 0\% cross-reactivity with mouse INSL3, with other human INSLs or human insulin, C-peptide, amylin, glucagon, GLP-1, GLP-2, ghrelin, calcitonin gene-related peptide (CGRP), agouti-related protein (AGRP) (83-132)-amide, and with human, porcine, and rat LHRH).

The INSL3 assay covers a reliable detection range between 0.05 and $2.80 \mathrm{ng} / \mathrm{ml}$ serum. The standard curve is well fitted by a four-parameter logistic function, the linear range being $0.15-1.18 \mathrm{ng} / \mathrm{ml}$. A dilution factor of 1:3 for the serum samples of all patients and controls was determined to be appropriate to ensure the samples to be within the dynamic range of the standard curve. Serum INSL3 concentrations were also measured in sera of postmenopausal women $(n=12)$, considered to be free from INSL3 (24), spiked with defined serial amounts of the synthetic standard peptide (from 0.1 to $1.0 \mathrm{ng} / \mathrm{ml}$ ). The measured INSL3 concentrations were $98-128 \%$ of the added standard, which is an acceptable accuracy. The intra-assay variation, evaluated by six parallel measurements of serum from five samples, ranged $1-5 \%$. The inter-assay variation, evaluated by six separate measurements of the serum from five patients and five controls, ranged $6-15 \%$. The effect of repeated cycles of freezing and thawing was evaluated by aliquoting samples of three controls and measuring the samples (in the same assay) after 0-4 cycles of $1 \mathrm{~h}$ freezing $\left(-20{ }^{\circ} \mathrm{C}\right)$ followed by thawing at room temperature. There was no significant effect of repeated freezing and thawing on the measured concentrations of serum INSL3.

\section{Statistical analysis}

Data are expressed as mean \pm s.D. Normal distribution of continuous variables was tested with the Kolmogorov-Smirnov test. Dummy variables, as diabetic comorbidities/complications, poor or optimal glycemic control, and visceral obesity were categorized as $0 / 1$ parameters. The hormonal and other measurements in the different groups were compared using the two-tailed Student's $t$-test for the normally distributed variables, whereas the nonparametric two-tailed Mann-Whitney test was used for the others. The ANOVA was used to compare the obese, overweight, and normal weight groups of patients. Fisher's exact test or $\chi^{2}$ test was also used to compare the categorical variables among the different groups. Correlations were assessed using the Pearson's correlation coefficient or Spearman rank order depending on whether the data were normally distributed. In all patients, multiple linear regression analysis was performed to evaluate the association between INSL3 levels (dependent variable) and several anthropometric, metabolic, hormonal parameters, and diabetic comorbidities/complications (independent variables). A $P$ value $<0.05$ was considered significant. Statistical analysis was performed using the SigmaStat for Windows 3.0 software (SPSS Inc., Chicago, IL, USA).

\section{Results}

\section{Evaluation of Leydig cell function in T2DM patients}

A trend to low total testosterone levels $(452.6 \pm 130.0$ vs $512.6 \pm 117.3 \mathrm{ng} / \mathrm{dl}, P=0.06)$ was found in T2DM patients with respect to age- and BMI-matched controls, without any difference in SHBG levels $(42.0 \pm 16.7$ vs $39.0 \pm 10.5 \mathrm{nmol} / \mathrm{l})$; however, significantly lower BT $(189.7 \pm 36.4$ vs $237.1 \pm 94.1 \mathrm{ng} / \mathrm{dl}, P=0.002)$ and cFT values $(8.1 \pm 1.6$ vs $10.1 \pm 4.0 \mathrm{ng} / \mathrm{dl}, P=0.002)$ and higher $\mathrm{LH}$ levels $(3.5 \pm 1.6$ vs $2.6 \pm 1.2 \mathrm{mU} / \mathrm{ml}$, $P=0.01$ ) were found (Fig. 1). Serum LH levels ranged $1.1-6.0 \mathrm{mU} / \mathrm{ml}$ in controls and $1.0-7.6 \mathrm{mU} / \mathrm{ml}$ in diabetic patients.

As far as the study of the testicular secretory reserve was concerned, the peak of testosterone release was observed $72 \mathrm{~h}$ after the administration of hCG. In control subjects, the mean testosterone increase was $730.5 \pm 70.7 \mathrm{ng} / \mathrm{dl}$. Thirteen patients had a testosterone response similar to controls, while a poor testosterone response (below 2 s.D. from the mean testosterone increase observed in controls) was observed in 17 out of the 30 patients (testosterone net increase $281.5 \pm 85.1 \mathrm{ng} / \mathrm{dl}, P=0.001)$.

Interestingly, serum INSL3 concentrations were significantly lower in patients with T2DM than controls $(1.1 \pm 0.3$ vs $1.5 \pm 0.7 \mathrm{ng} / \mathrm{ml}, P=0.01$; Fig. 2$)$. No significant correlations were found between serum INSL3 and basal or stimulated testosterone levels, bioT, cFT, PSA, and LH levels.

\section{Influence of glycemic control on the markers of Leydig cell function in T2DM patients}

To identify a possible influence of differences in glycemic control on the HPG axis function, a subset of 15 patients with poor glycemic control (group A, HbAlc $>9 \%$, age $54.9 \pm 6.7$ years, BMI $27.7 \pm 4.2 \mathrm{~kg} / \mathrm{m}^{2}$, waist circumference $99.1 \pm 12.0 \mathrm{~cm}$ ) were compared with the other 15 patients with good glycemic control (group B, $\mathrm{HbA} 1 \mathrm{c}<7 \%$, age $58.6 \pm 5.4$ years, BMI 28.5 $\pm 4.6 \mathrm{~kg} / \mathrm{m}^{2}$, waist circumference $96.8 \pm 13.3 \mathrm{~cm}$ ). The two groups were similar for anthropometric and metabolic features (Table 1).

Serum testosterone, as well as BT and cFT values, serum LH, and INSL3 levels were not different between 

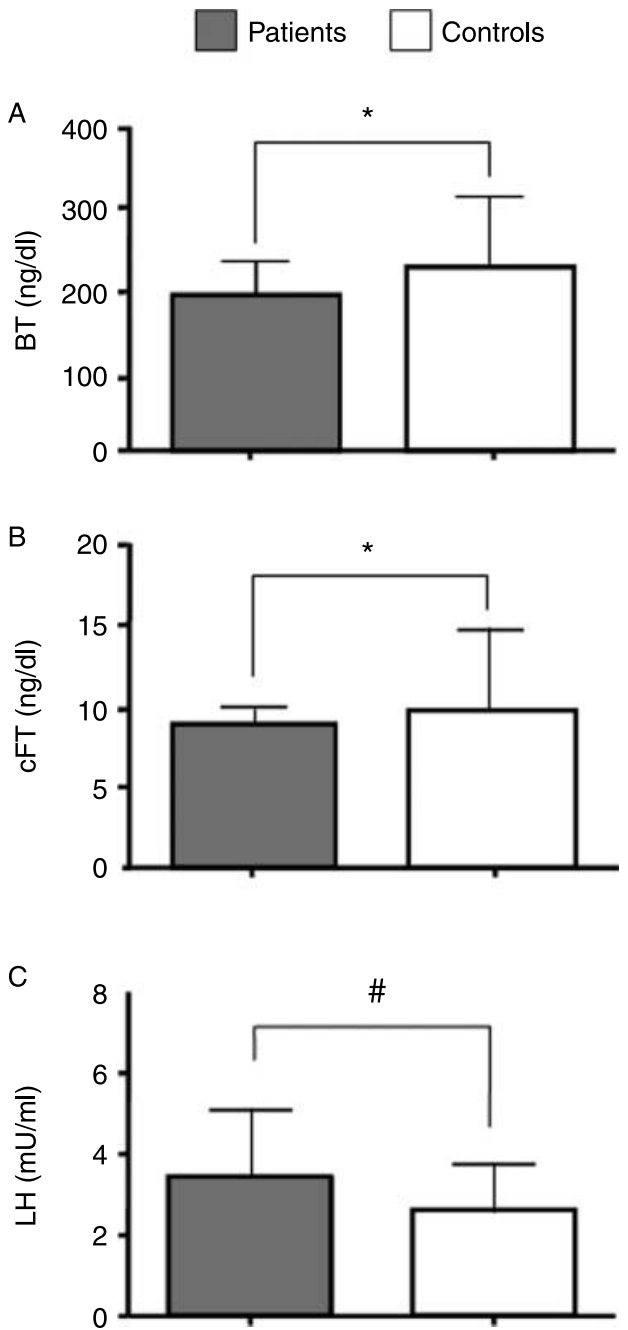

Figure 1 Bioavailable (BT, panel A), calculated free testosterone (cFT, panel B), and LH levels (panel C) in 30 patients affected by type 2 diabetes mellitus without overt hypogonadism (gray columns), compared with age- and BMI-matched controls (white columns) (mean \pm s.D.); ${ }^{*} P=0.002,{ }^{\#} P=0.01$.

patients with poorly controlled or well-controlled T2DM. Also the testicular response to hCG stimulation was not different between the two subgroups (Table 1). The simple correlation analysis did not show any relationship between glycemic control and basal or stimulated hormonal levels, as well as with serum INSL3 levels.

\section{Effect of visceral adiposity on the markers of Leydig cell function in T2DM patients}

BMI did not show any significant correlation with the Leydig cells function parameters. Comparing obese diabetic patients $\left(n=9\right.$; BMI $\left.33.6 \pm 3.3 \mathrm{~kg} / \mathrm{m}^{2}\right)$, overweight patients $\left(n=12\right.$; BMI $\left.27.2 \pm 1.2 \mathrm{~kg} / \mathrm{m}^{2}\right)$, and normal weight patients $\left(n=9\right.$; BMI $\left.23.9 \pm 0.7 \mathrm{~kg} / \mathrm{m}^{2}\right)$, the three groups did not differ in basal or
hCG-stimulated testosterone $(401.8 \pm 127.2$ vs 502.0 \pm 120.2 vs $437.7 \pm 135.7$ and $775.0 \pm 375.8$ vs $987.9 \pm 445.7$ vs $927.8 \pm 279.9 \mathrm{ng} / \mathrm{dl}$ respectively), SHBG $(34.6 \pm 16.6$ vs $50.2 \pm 16.8$ vs 38.4 $\pm 13.1 \mathrm{nmol} / \mathrm{l})$, BT $(189.4 \pm 42.3$ vs $188.8 \pm 31.2$ vs $191.0 \pm 40.9 \mathrm{ng} / \mathrm{dl}), \quad \mathrm{cFT}(8.0 \pm 1.7$ vs $8.1 \pm 1.6$ vs $8.1 \pm 1.7 \mathrm{ng} / \mathrm{dl})$, LH $(3.1 \pm 1.0$ vs $4.4 \pm 1.9$ vs 2.9 $\pm 1.3 \mathrm{mU} / \mathrm{ml})$ as well as INSL3 levels $(0.9 \pm 0.3 \mathrm{vs}$ $1.3 \pm 0.4$ vs $1.0 \pm 0.1 \mathrm{ng} / \mathrm{ml})$. Similarly, percentage of fat mass was not significantly associated with basal or stimulated hormonal levels.

Interestingly, the waist circumference (97.9 $\pm 12.4 \mathrm{~cm}$ ) was negatively associated with both basal testosterone $(r=-0.374, P=0.04)$ and the testosterone peak increase after hCG stimulation $(r=-0.511$, $P=0.004)$, though no correlation was found between waist circumference and LH levels. In order to investigate the relationship between the waist circumference and serum INSL3 levels after adjusting for the possible confounding factors, a multivariate analysis has been performed. In the multiple linear regression model, waist circumference, age, hypertension, dyslipidemia, glycemic control, use of insulin or insulin sensitizers, and LH levels were considered as independent variables: only the waist was negatively correlated with serum INSL3 levels $(r=0.647, \beta=-0.016$, $P=0.03)$. Either BMI or percentage of fat mass, considered as independent variables in this model, did not correlate with serum INSL3 levels.

\section{Symptoms of sexual dysfunction}

The presence of ED was found in 12 out of 30 patients $(40 \%)$. In all cases, the SIEDY scale 1 score confirmed the presence of an organic disturbance underlying ED, as expected since the diagnosis of diabetes contributes to the scale's score. All the patients with ED had an ANDROTEST score $<8$.

Patients with ED did not show different basal or stimulated hormonal levels, compared with patients

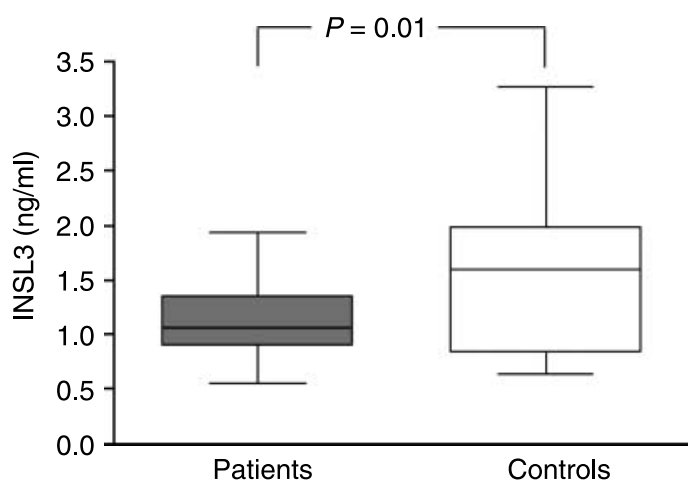

Figure 2 Serum INSL3 concentrations in 30 patients affected by type 2 diabetes mellitus without overt hypogonadism, compared with age- and BMI-matched controls. 
Table 1 Anthropometric, metabolic, and hormonal features of patients with poorly controlled (group A) or well-controlled (group B) type 2 diabetes mellitus.

\begin{tabular}{|c|c|c|c|}
\hline & $\begin{array}{c}\text { Group A } \\
(n=15)\end{array}$ & $\begin{array}{c}\text { Group B } \\
(n=15)\end{array}$ & $\boldsymbol{P}$ \\
\hline \multicolumn{4}{|l|}{ Anthropometric features } \\
\hline Age (years) & $54.9 \pm 6.7$ & $58.6 \pm 5.4$ & NS \\
\hline BMI $\left(\mathrm{kg} / \mathrm{m}^{2}\right)$ & $27.7 \pm 4.2$ & $28.5 \pm 4.6$ & NS \\
\hline $\begin{array}{l}\text { Waist circumference } \\
\text { (cm) }\end{array}$ & $99.1 \pm 12.0$ & $96.8 \pm 13.3$ & NS \\
\hline WHR & $0.99 \pm 0.08$ & $0.95 \pm 0.06$ & NS \\
\hline Fat mass (\%) & $24.5 \pm 5.4$ & $29.1 \pm 7.0$ & NS \\
\hline \multicolumn{4}{|l|}{ Metabolic features } \\
\hline $\mathrm{HbA} 1 \mathrm{c}(\%)$ & $10.5 \pm 1.7$ & $6.6 \pm 0.3$ & $<0.001$ \\
\hline Glucose $(\mathrm{mg} / \mathrm{dl})$ & $204.1 \pm 76.9$ & $124.9 \pm 31.6$ & 0.003 \\
\hline $\begin{array}{l}\text { Total cholesterol } \\
(\mathrm{mg} / \mathrm{dl})\end{array}$ & $201.8 \pm 52.9$ & $190.8 \pm 38.2$ & NS \\
\hline $\begin{array}{l}\text { LDL cholesterol } \\
(\mathrm{mg} / \mathrm{dl})\end{array}$ & $129.0 \pm 38.6$ & $116.1 \pm 28.3$ & NS \\
\hline $\begin{array}{l}\text { HDL cholesterol } \\
(\mathrm{mg} / \mathrm{dl})\end{array}$ & $42.7 \pm 11.4$ & $44.4 \pm 11.9$ & NS \\
\hline Triglycerides $(\mathrm{mg} / \mathrm{dl})$ & $150.7 \pm 59.3$ & $124.4 \pm 51.0$ & NS \\
\hline $\begin{array}{l}\text { Duration of diabetes } \\
\text { (years) }\end{array}$ & $9.3 \pm 8.1$ & $5.1 \pm 4.7$ & NS \\
\hline Insulin therapy (\%) & 33.3 & 20.0 & NS \\
\hline \multicolumn{4}{|l|}{ Hormonal features } \\
\hline $\begin{array}{l}\text { Total testosterone } \\
(\mathrm{ng} / \mathrm{dl})\end{array}$ & $459.9 \pm 134.8$ & $445.4 \pm 129.3$ & NS \\
\hline SHBG $(\mathrm{nmol} / \mathrm{l})$ & $40.5 \pm 20.5$ & $43.4 \pm 12.3$ & NS \\
\hline BT $(n g / d l)$ & $197.9 \pm 33.6$ & $181.4 \pm 38.3$ & NS \\
\hline $\mathrm{cFT}(\mathrm{ng} / \mathrm{dl})$ & $8.6+1.6$ & $7.6+1.5$ & NS \\
\hline $\mathrm{LH}(\mathrm{mU} / \mathrm{ml})$ & $3.4 \pm 1.5$ & $3.7 \pm 1.8$ & NS \\
\hline $\begin{array}{l}\text { Testosterone net } \\
\text { increase }(\mathrm{ng} / \mathrm{dl})^{\mathrm{a}}\end{array}$ & $452.8 \pm 309.6$ & $454.0 \pm 261.8$ & NS \\
\hline INSL3 (ng/ml) & $1.2 \pm 0.3$ & $1.0 \pm 0.4$ & NS \\
\hline
\end{tabular}

WHR, waist-to-hip ratio; BT, bioavailable testosterone; cFT, calculated free testosterone; NS, not significant.

${ }^{\mathrm{a}}$ Testosterone increase after hCG testing.

without ED; also serum INSL3 concentrations were not different between patients with or without ED.

Glycemic control did not differ between patients with or without ED (data not shown). As far as anthropometric features are concerned, waist circumference was higher in patients with ED $(103.7 \pm 13.9$ vs 93.9 $\pm 9.9 \mathrm{~cm}, P=0.03)$, whereas WHR, BMI, or $\%$ fat mass was not different.

\section{Discussion}

The frequent occurrence of overt hypogonadism in men with T2DM has been recently reported $(2,3,6,7)$. Indeed, the present findings firstly suggest the existence of subtle alterations at gonadal level also in diabetic patients with normal testosterone values, regardless of the presence of symptoms of androgen deficiency. The global impairment of Leydig cell function in T2DM is confirmed by the finding of reduced circulating levels of INSL3, a novel peptide hormone mainly derived from Leydig cells $(15,16,25,26)$, which have been indicated as an absolute measure of either quality or number of the Leydig cells, independently from gonadotropin stimulation $(16,17,27-30)$. The higher LH levels in diabetic patients than in controls, though in the normal range, might suggest that when few or poor-quality Leydig cells are present, more LH is required to achieve normal circulating testosterone levels. Since the presence of the INSL3 receptor has been demonstrated at pituitary level, a possible negative feedback of INSL3 has also been hypothesized (15). Finally, the observation of an inadequate testosterone response to hCG administration in a relevant number of cases is in line with the hypothesis of an early primary Leydig cell impairment in patients with T2DM without severe obesity. Indeed, both hypothalamic/pituitary and testicular defects have been associated with the presence of low testosterone levels in T2DM. Inappropriately normal gonadotropin levels that rose after $\mathrm{GnRH}$ in hypogonadal type 2 diabetic patients, as well as low gonadotropin levels in hypogonadal compared with eugonadal T2DM patients, have been reported, suggesting a hypothalamic defect, ascribed to the presence of obesity/insulin resistance $(2,10,31)$. Therefore, patients with severe obesity were excluded from the present study. The present findings in T2DM patients are in line with Pitteloud et al. (11), who investigated the HPG axis in men with impaired glucose tolerance and found a low testosterone responsiveness to hCG administration. The authors reported a strong correlation between insulin sensitivity and the testosterone response to hCG, while no relationship between insulin sensitivity and some parameters of LH secretion was found, suggesting that insulin resistance is in part associated with a decrease in Leydig cell testosterone secretion (11). Unfortunately, due to the presence of different confounding medications, as insulin sensitizers or exogenous insulin itself, we could not provide an index of insulin resistance in our population. Finally, hyperleptinemia has been reported to impair Leydig response to hCG in obese subjects (32). Hyperleptinemia, which is common also in diabetic patients, might contribute to the reduced testosterone response to hCG observed in the present series.

Serum INSL3 levels have been reported to be significantly correlated with testosterone and LH levels in patients with testicular disorders $(15,16)$. In the present study, INSL3 was successfully detected in the serum of both diabetic patients and controls by the EIA assay giving results similar to previous data obtained by the INSL3 time-resolved fluorescence immunoassay (TRFIA) $(16,17)$. Nonetheless, serum INSL3 levels did not show a significant correlation with both testosterone and LH levels in diabetic patients and controls. This lack of correlation might be related to the low degree of the Leydig cell function impairment, as a significant correlation between serum INSL3 and testosterone or $\mathrm{LH}$ levels has not been reported also in a large cohort of healthy men (17). Indeed, we cannot exclude that it might depend on the small size of our series. 
As far as the association between glycemic control and Leydig cell function is concerned, no differences in the HPG axis or in INSL3 concentrations were found, when comparing patients with poor and good glycemic control. Previous studies taking into account the glycemic control in the evaluation of diabetesrelated hypogonadism reported conflicting results, showing either an association $(1,12,13)$ or a lack of association $(2,3,5,7,14)$ between glycemic control and testosterone levels. Our findings suggest glycemic control as an unlikely major determinant factor affecting Leydig cell function or the HPG axis at various levels, whereas it may be a confounding factor in type 2 diabetic patients.

Interestingly, a relevant finding of our study is the negative association between visceral adiposity and either markers of Leydig cell function, as serum testosterone levels in basal conditions and after hCG administration, and the new marker INSL3. This negative association between obesity and INSL3 levels has been recently reported in severe obese subjects by Foresta et al. (33). Indeed, we found that waist circumference, rather than BMI, is inversely associated with INSL3 levels in diabetic patients. Recent studies showed an association between visceral adiposity and low testosterone levels in T2DM $(4,6)$, partly attributed to the hypogonadal-obesity cycle, involving an increased aromatase activity of visceral adipocytes (34). Moreover, it is well known that visceral adipose tissue is able to produce and release a wide variety of pro- and anti-inflammatory cytochemokines, as leptin or tumour necrosis factor- $\alpha$, possibly affecting Leydig cell steroidogenesis also in humans $(11,32,35-37)$. Therefore, it is tempting to speculate that the chronic low-grade inflammatory syndrome associated with visceral obesity and T2DM may affect the overall Leydig cell function. It is of note that the presence of LH levels in the normal range, although higher than controls, in T2DM patients with reduced INSL3 levels might depend on an inhibitory effect of adipocytokines on the hypothalamic-pituitary axis: this finding is in line with the high incidence of hypogonadism, even with normal LH levels, in obese men (38).

Though the ED was present in $40 \%$ of the present series of nonhypogonadal diabetic patients, no significant correlation between ED and gonadal function as well as glycemic control could be found. Indeed, visceral adiposity was associated with ED, in agreement with recent reports (39-41).

In conclusion, the present data from a small cohort suggest that an early Leydig cell impairment may be found in T2DM patients without overt hypogonadism and that it does not seem to be related to ED symptoms and glycemic control. The presence of an association between these alterations and visceral adiposity supports the relevance of visceral obesity evaluation in these subjects.

\section{Declaration of interest}

There is no conflict of interest that could be perceived as prejudicing the impartiality of the research reported.

\section{Funding}

This study was partially supported by grants from FIRST 2007, University of Milano and from IRCCS Policlinico San Donato.

\section{Acknowledgements}

We thank Dr Fabio Giavazzi for the statistical analysis and the helpful discussion.

\section{References}

1 Barrett-Connor E, Khaw KT \& Yen SS. Endogenous sex hormone levels in older adult men with diabetes mellitus. American Journal of Epidemiology 1990132 895-901.

2 Dhindsa S, Prabhakar S, Sethi M, Bandyopadhyay A, Chaudhuri A \& Dandona P. Frequent occurrence of hypogonadotropic hypogonadism in type 2 diabetes. Journal of Clinical Endocrinology and Metabolism 200489 5462-5468.

3 Corona G, Mannucci E, Petrone L, Ricca V, Balercia G, Mansani R, Chiarini V, Giommi R, Forti G \& Maggi M. Association of hypogonadism and type II diabetes in men attending an outpatient erectile dysfunction clinic. International Journal of Impotence Research 200618 190-197.

4 Corona G, Mannucci E, Petrone L, Balercia G, Paggi F, Fisher AD, Lotti F, Chiarini V, Fedele D, Forti G \& Maggi M. NCEP-ATPIIIdefined metabolic syndrome, type 2 diabetes mellitus, and prevalence of hypogonadism in male patients with sexual dysfunction. Journal of Sexual Medicine 20074 1038-1045.

5 Fukui M, Soh J, Tanaka M, Kitagawa Y, Hasegawa G, Yoshikawa T, Miki T \& Nakamura N. Low serum testosterone concentration in middle-aged men with type 2 diabetes. Endocrine Journal $2007 \mathbf{5 4}$ $871-877$

6 Kapoor D, Aldred H, Clark S, Channer KS \& Jones TH. Clinical and biochemical assessment of hypogonadism in men with type 2 diabetes: correlations with bioavailable testosterone and visceral adiposity. Diabetes Care 200730 911-917.

7 Grossmann M, Thomas MC, Panagiotopoulos S, Sharpe K, Macisaac RJ, Clarke S, Zajac JD \& Jerums G. Low testosterone levels are common and associated with insulin resistance in men with diabetes. Journal of Clinical Endocrinology and Metabolism 2008 95 1834-1840.

8 Ali ST, Shaikh RN, Ashfaqsiddiqi N \& Siddiqi PQ. Serum and urinary levels of pituitary-gonadal hormones in insulin-dependent and non-insulin-dependent diabetic males with and without neuropathy. Archives of Andrology 199330 117-123.

9 Ando S, Rubens R \& Rottiers R. Androgen plasma levels in male diabetics. Journal of Endocrinological Investigation 19847 21-24.

10 Tripathy D, Dhindsa S, Garg R, Khaishagi A, Syed T \& Dandona P. Hypogondotrophic hypogonadism in erectile dysfunction associated with type 2 diabetes mellitus: a common defect? Metabolic Syndrome and Related Disorders 20031 75-81.

11 Pitteloud N, Hardin M, Dwyer AA, Valassi E, Yialamas M, Elahi D \& Hayes FJ. Increasing insulin resistance is associated with a decrease in Leydig cell testosterone secretion in men. Journal of Clinical Endocrinology and Metabolism 200590 2636-2641.

12 Boyanov MA, Boneva Z \& Christov VG. Testosterone supplementation in men with type 2 diabetes, visceral obesity and partial androgen deficiency. Aging Male 20036 1-7.

13 Kapoor D, Goodwin E, Channer KS \& Jones TH. Testosterone replacement therapy improves insulin resistance, glycaemic 
control, visceral adiposity and hypercholesterolaemia in hypogonadal men with type 2 diabetes. European Journal of Endocrinology 2006154 899-906.

14 Corrales JJ, Burgo RM, Garca-Berrocal B, Almeida M, Alberca I, Gonzalez-Buitrago JM, Orfa A \& Miralles JM. Partial androgen deficiency in aging type 2 diabetic men and its relationship to glycemic control. Metabolism 200453 666-672.

15 Foresta C, Bettella A, Vinanzi C, Dabrilli P, Meriggiola MC, Garolla A \& Ferlin A. A novel circulating hormone of testis origin in humans. Journal of Clinical Endocrinology and Metabolism 2004 89 5952-5958.

16 Bay K, Hartung S, Ivell R, Schumacher M, Jurgensen D, Jorgensen N, Holm M, Skakkebaek NE \& Andersson AM. Insulinlike factor 3 serum levels in 135 normal men and 85 men with testicular disorders: relationship to the luteinizing hormonetestosterone axis. Journal of Clinical Endocrinology and Metabolism $2005903410-3418$.

17 Anand-Ivell R, Wohlgemuth J, Haren MT, Hope PJ, Hatzinikolas G, Wittert G \& Ivell R. Peripheral INSL3 concentrations decline with age in a large population of Australian men. International Journal of Andrology $200629618-626$.

18 Bhasin S, Cunningham GR, Hayes FJ, Matsumoto AM, Snyder PJ, Swerdloff RS \& Montori VM. Testosterone therapy in adult men with androgen deficiency syndromes: an endocrine society clinical practice guideline. Journal of Clinical Endocrinology and Metabolism 200691 1995-2010.

19 Petrone L, Mannucci E, Corona G, Bartolini M, Forti G, Giommi R \& Maggi M. Structured interview on erectile dysfunction (SIEDY): a new, multidimensional instrument for quantification of pathogenetic issues on erectile dysfunction. International Journal of Impotence Research 200315 210-220.

20 Corona G, Mannucci E, Petrone L, Balercia G, Fisher AD, Chiarini V, Forti G \& Maggi M. ANDROTEST: a structured interview for the screening of hypogonadism in patients with sexual dysfunction. Journal of Sexual Medicine 20063 706-715.

21 Alberti KG, Zimmet P, Shaw J \& IDF Epidemiology Task Force Consensus Group. The metabolic syndrome - a new worldwide definition. Lancet 2005366 1059-1062.

22 Vermeulen A, Verdonck L \& Kaufman JM. A critical evaluation of simple methods for the estimation of free testosterone in serum. Journal of Clinical Endocrinology and Metabolism $1999 \mathbf{8 4}$ 3666-3672.

23 Morley JE, Patrick P \& Perry HM III. Evaluation of assays available to measure free testosterone. Metabolism 200251 554-559.

24 Bamberger AM, Ivell R, Balvers M, Kelp B, Bamberger CM, Riethdorf L \& Loning T. Relaxin-like factor (RLF): a new specific marker for Leydig cells in the ovary. International Journal of Gynecological Pathology 199918 163-168.

25 Burkhardt E, Adham IM, Hobohm U, Murphy D, Sander C \& Engel W. A human cDNA coding for the Leydig insulin-like peptide (Ley I-L). Human Genetics 199494 91-94.

26 Büllesbach EE, Rhodes R, Rembiesa B \& Schwabe C. The relaxinlike factor is a hormone. Endocrine 1999 10 167-169.

27 Ivell R, Balvers M, Domagalski R, Ungefroren H, Hunt N \& Schulze W. Relaxin-like factor: a highly specific and constitutive new marker for Leydig cells in the human testis. Molecular Human Reproduction 19973 459-466.
28 Balvers M, Spiess AN, Domagalski R, Hunt N, Kilic E, Mukhopadhyay AK, Hanks E, Charlton HM \& Ivell R. Relaxinlike factor expression as a marker of differentiation in the mouse testis and ovary. Endocrinology 1998139 2960-2970.

29 Sadeghian H, Anand-Ivell R, Balvers M, Relan V \& Ivell R. Constitutive regulation of the Insl3 gene in rat Leydig cells. Molecular and Cellular Endocrinology 2005241 10-20.

30 Bay K, Matthiesson KL, McLachlan RI \& Andersson AM. The effects of gonadotropin suppression and selective replacement on insulin-like factor 3 secretion in normal adult men. Journal of Clinical Endocrinology and Metabolism $2006 \mathbf{9 1}$ 1108-1111.

31 Vermeulen A, Kaufman JM, Deslypere JP \& Thomas G. Attenuated luteinizing hormone (LH) pulse amplitude but normal $\mathrm{LH}$ pulse frequency, and its relation to plasma androgens in hypogonadism of obese men. Journal of Clinical Endocrinology and Metabolism 1993 76 1140-1146.

32 Isidori AM, Caprio M, Strollo F, Moretti C, Frajese G, Isidori A \& Fabbri A. Leptin and androgens in male obesity: evidence for leptin contribution to reduced androgen levels. Journal of Clinical Endocrinology and Metabolism 199984 3673-3680.

33 Foresta C, Di Mambro A, Pagano C, Garolla A, Vettor R \& Ferlin A. Insulin-like factor 3 as a marker of testicular function in obese men. Clinical Endocrinology, 2009. In press. DOI: 10.1111/j. 1365-2265.2009.03549.x.

34 Cohen PG. The hypogonadal-obesity cycle. Medical Hypotheses 199952 49-51.

35 Saez JM. Leydig cells: endocrine, paracrine, and autocrine regulation. Endocrine Reviews 199415 574-626.

36 Caprio M, Isidori AM, Carta AR, Moretti C, Dufau ML \& Fabbri A. Expression of functional leptin receptors in rodent Leydig cells. Endocrinology $19991404939-4947$.

37 Morales V, Santana P, Diaz R, Tabraue C, Gallardo G, Lopez Blanco F, Hernandez I, Fanjul LF \& Ruiz de Galarreta CM. Intratesticular delivery of tumor necrosis factor-a and ceramide directly abrogates steroidogenic acute regulatory protein expression and Leydig cell steroidogenesis in adult rats. Endocrinology $2003 \mathbf{1 4 4} 4763-4772$.

38 Jones TH. Testosterone associations with erectile dysfunction, diabetes, and the metabolic syndrome. European Urology Supplements 20076 847-857.

39 Kapoor D, Clarke S, Channer KS \& Jones TH. Erectile dysfunction is associated with low bioactive testosterone levels and visceral adiposity in men with type 2 diabetes. International Journal of Andrology $2007 \mathbf{3 0} 500-507$.

40 Traish AM, Guay A, Feeley R \& Saad F. The dark side of testosterone deficiency: I Metabolic syndrome and erectile dysfunction. Journal of Andrology 200930 10-22.

41 Corona G, Mannucci E, Forti G \& Maggi M. Hypogonadism, ED, metabolic syndrome and obesity: a pathological link supporting cardiovascular diseases. International Journal of Andrology, 2009. In press. DOI: 10.1111/j.1365-2605.2008.00951.x.

Received 30 July 2009

Accepted 30 August 2009 